\title{
ESVA pohti vuosikongressissaan yhdistysten merkitystä aikuiskasvatuksessa
}

Leidenin yliopiston ja Unkarin kansallisen kulttuurikeskuksen, Hungarian National Centre for Culture, yhteistyössä organisoima ESVAn, European Symposium on Voluntary Associations, vuosikongressi pidettiin Leidenin lähistöllä OutPoelgeestin koulutuskeskuksessa lokakuussa. Tapaamisen pääteemana oli yhdistystoiminnan ja erityyppisten sosiaalisten liikkeiden asema aikuiskasvatuksen agentteina sekä vapaaehtoisen yhdistystoiminnan kasvatuksellinen luonne ja vaikutus.

Osallistujia oli 13 maasta Länsi- ja Itä-Euroopasta. Suurin osa oli isäntämaan sekä Neuvostoliiton ja Unkarin edustajia.

Vaikka yhdistystoimintaan liittyvä kasvatuksellinen problematiikka jäi yleisesitelmissä melko vähille - osin peruuntumisista johtuen - nähtiin tutkimusalueiden integrointi tärkeänä, kasvatuksen ja kansalaistoiminnan kenttien yhteyksien kartoitus eri maita vertailevasta näkökulmasta on jatkossa ESVAn eräänä pääteemana. Nyt pidetty kongressi avasi ja kartoitti kysymysaluetta, ei niinkään muovannut selkeästi uutta tutkimusperinnettä. Tutkimustematiikan kehittymisen kannalta kongressi toi esiin joitakin tutkimustavallisia kiintopisteitä, jotka ainakin osin sijoittuvat läntisen Euroopan ja entisten sosialististen maiden väliseen vedenjakajaan.

Kansalaistoiminnan ja aikuiskasvatuksen perustilanne poikkeaa entisissä sosialistisissa maissa läntisestä Euroopasta siinä, että kansalaisyhteiskunnalliset aktiviteetit ovat olemassa vasta idullaan ja rakentumassa reaalisosialismin raunioiden päälle. Kulttuurista perustaa ei tälle raken- nustyölle ole tai jos on, nïn äärimmäisen ohuessa muodossa, ennen II maailmansotaa eläneiden sukupolvien sosiaalisessa muistissa. Tällainen on tilanne esimerkiksi Unkarissa. Tämä kulttuurisesti osin avoimeksi ja osin jopa tyhjäksi luonnehdittu tilanne heijastuu tutkimusratkaisuissa ja -vaihtoehdoissa tapaustutkimuksiin suuntautumisena.

Läntistä Eurooppaa koskevissa yleis- ja työryhmäesityksissä painottuivat historialliset ja osin teoreettiset näkökulmat. Konkreettisemmin esitykset voidaan karkeasti kiteyttää valtiollisen sääntelyn purkautumisesta koskevien seurauksien arviointiin, valtiollisen ohjauksen ongelmiin, vapaaehtoisen kansalaistoiminnan ja kasvatuksen merkitykseen historiassa ja nykypäivänä sekä kansainvälistymisen kasvatuksellisiin edellytyksiin ja kansainvälistymisen mukanaan tuomien aikuiskasvatuksen kehittämismahdollisuuksien tarkasteluun eri tyyppisillä foorumeilla.

Kansalaistoiminnan ja tähän liittyvän kasvatuksen merkitykselle löytyy yhteinen nimittäjä yhtäältä niistä läntistä Eurooppaa koskevista taloudellisista, sosiaalisista ja kulttuurisista uudelleenrakentautumisprosesseista sekä toisaalta entisten sosialististen maiden kulttuurisesti idullaan olevasta tilanteesta.

Molemmissa murrosprosesseissa tuotiin esiin mahdollisuus, että eri tyyppiset sosiaaliset ongelmat ovat tulevan kansalaistoiminnan ja -kasvatuksen ydintä. Sosiaalisten ongelmien lähde on läntisessä Euroopassa hyvinvointivaltion purkamissa, entisissä sosialistisissa maissa kulttuurisen ja sosiaalisen tyhjiön muodostumisessa. 